\title{
Venture Capital Decision Based on POC Framework
}

\author{
Yuze $\mathrm{Gao}^{1,{ }^{,}, \mathrm{a}, \dagger}$, Ziqian Weng ${ }^{2,{ }^{*}, \mathrm{~b}, \dagger}$, Menghan $\mathrm{Yu}^{3,{ }^{*}, \mathrm{c}, \dagger}$
}

\author{
${ }^{1}$ School of Finance, Nankai University, Tianjin, China \\ ${ }^{2}$ School of Finance, Zhejiang University of Finance \& Economics, Zhejiang, China \\ ${ }^{3}$ School of Commerce, AIDI school, Beijing, China \\ *Corresponding author.Email: ${ }^{a} 1914032 @ m a i l . n a n k a i . e d u . c n,{ }^{b}$ koalaqian@zufe.edu.cn, ${ }^{c}$ a1810062@aidi.edu.cn \\ These authors contributed equally.
}

\begin{abstract}
Venture capital investment is considered a high-risk, high-return asset class. It helps enterprises, especially start-ups, to broaden the business and increase company value. In this article, we research to evaluate the investment valuation of Trans Tech, a state-owned company working in the ETC industry. Firstly, we analyze the main business and profit situation to look into its operation conditions and development prospect. Then it comes to the key point in our research: Competition analysis with POCD framework. In our investigation of the company from three perspectives (people, opportunity, and context), the framework has shown its advantages for its requirement to understand plentiful information about the company, such as its establishment background, developing history, and present operation management. We find out it has a professional and mature core team, a bright market prospect, and strong and stable policy support, a crucial factor of ETC. And through the POC framework, it comes out that Trans Tech has merits that outweighed its demerits. Therefore, we decided to invest in the IPO of the company.
\end{abstract}

Keywords: Venture capital; POC framework; ETC business; Trans Tech; investment potential.

\section{INTRODUCTION}

A venture capitalist (VC) is a private equity investor that provides capital to small companies with high growth potential to help them develop and expand to gain market share. During the process of investing, the VCs could receive an equity stake of their target firms. Still, they also experience high failure rates due to the uncertainty involved with new and unproven companies. At present, the market is full of start-ups in various industries, which puts forward more rigorous requirements for the ability of VCs. They are confronted with both risk and huge profits when choosing to invest in an early-stage company.

Since most of the startups don't have a steady flow of cash which is quite important for the normal operation of all enterprises, in other words, a successful startup may not have positive profits, but it will struggle without cash flow. Venture capitalists are key roles in providing cash flow and operational support to the startups if they favor. They usually show great interest in industries that can solve hot social issues. Now that the rapid development of science and technology brings us convenience and brings us a lot of social problems like traffic congestion caused by the sharp rise in car ownership. However, with the gradual maturity from big data to $5 \mathrm{G}$, intelligent transport emerged at the historic moment and coruscated a huge vitality that will play an increasingly important role shortly. Trans Tech is one of the leading national suppliers that provides the intelligent transportation platform of the expressway as well as urban traffic. The analysis of the POCD (people, opportunity, context, deal) framework and main firm business, profit situation, and major competitors conclude whether the company is worth investing in.

There is a lot of literature that investigates start-up investment. Both academics and practitioners generally consider venture capital (VC, henceforth) the most suitable financing mode for entrepreneurial firms [1]. VC organizations raise money from individuals and institutions for investment in early-stage businesses that offer high potential but high risk [2]. For entrepreneurial firms, venture capital is an extremely important stakeholder, which can help entrepreneurial firms to create and obtain value through their industry expertise and network resources [3], such as the investment of Tencent in Trans Tech. Apart from this, VCs provide value-adding services $[4,5]$, like coaching, mentoring, and access to investment bankers, which could have signaling effects [6]. Furthermore, the extant literature 
has shown how venture capitalists play a key role in the post-investment monitoring of the portfolio firm [7]. Although VCs can provide such benefits to firms, in a challenging environment, they are at great risk. The trend of returns generated from early-round investing to lateround decreases generally: early investors get a higher return than late-stage investors, and IPO exits entail the highest return [8]. Besides, VC investments are prone to information asymmetry and agency costs, and, like any other investment, they also attract capital gains taxes [9]. Therefore, although there are still good opportunities to invest in early-stage projects, such transactions can be complicated [10]. It's indispensable for VCs to make a proper decision. Yang [11] researched that venture investment decisions can use machine learning to apply pre-optimized transactions, company data, founder data, etc., and understand how venture capitalists use artificial intelligence tools and methods to improve venture capital decisions. Sahlman [12] developed a conceptual framework for understanding entrepreneurial venture creation and management. In the framework, there are four dynamic components of any entrepreneurial process or venture----the people, the opportunity, the external context, and the deal. And this POCD framework will be used in our analysis.

In this research, we choose the POCD framework as the main research model. POCD framework and set of questions are extremely powerful in understanding how ventures evolve over time and how managers can affect outcomes. The balanced emphasis on anticipating (as opposed to predicting) good and bad news is a distinctive feature of the framework. For the POCD framework, we divide the main variables into three factors, namely, people's opportunities and content. In terms of people, there is no doubt that Transfer Tech is a highly experienced technology intelligent company held by a state-owned company. Most of its shareholders are experienced practitioners. From the perspective of opportunity, the development of the highway industry is faced with many opportunities and challenges. Dynamic government policies determine most. In terms of content, the competition in the whole industry is relatively less intense because most enterprises are state-owned enterprises or private enterprises bidding to enter the industry. However, due to the policy support from the government, they still have a large profit space, while the competition is relatively small, so ETC is a worthwhile industry to invest in. We firstly analyzed the ETC industry and some data from the annual report to evaluate the financial situation. The first section describes the basic operation, income, and financing of the company and its industries. The second section mainly uses the POCD model to analyze the opportunity and threatens of the company in terms of people, opportunities, and context. The third section mainly describes is that in the industry competition, the advantages and disadvantages of the company. Section four is investment decisions and development-driven from the above analysis. The last section presents our conclusion.

\section{FIRM DESCRIPTION}

\subsection{Main Business}

Trans Tech is one of the leading national suppliers that provides the intelligent transportation platform of the expressway as well as urban traffic. The company's main business includes ETC (Electronic Toll Collection), an intelligent transportation operation management system based on cloud computing, and derivative services related to intelligent transportation.

\subsubsection{ETC}

There are mainly three kinds of ETC sales services in ETC: direct selling, offline and online selling. Trans Tech has owned $1750 \mathrm{M}$ customers, which ranked the third nationwide by the end of 2019. Supported by the Jiangsu Province Government, the company laid out the ETC system in many scenarios such as hospitals, commercial centers, and so many other large transport hubs, which greatly improved the traffic condition.

\subsubsection{Operation Management System}

Trans Tech carries out business cooperation with the major regions like Hunan, Beijing, Shandong to expand the market and put forward the construction method of Multi-functional Sensing Traffic Platform for the first time, promoting the digital transformation of the expressway industry. What's more, the Trans Tech has shortened the accident handling time of Jiangsu Province expressway by $20 \%$, which made the public transport system more efficient.

\subsubsection{Derivative Services}

Trans Tech offers several derivative services like a vehicle insurance agent to increase customer stickiness. The vehicle insurance agent is a product customization service combined with traditional driving accident insurance, and now it has sold over 65M. Trans Tech has already cooperated with many banks, factoring companies and insurance companies, and other capital parties to solve the fund demand problem in small and micro businesses.

\subsection{Profit Situation}

After analyzing the main business of Trans Tech, we use financial analysis to determine whether the company is worth investing in. We found the data of main business income composition, main business cost composition, and the financing situation from the prospectus of Trans Tech. since the company was established in November 
2016 so we collected the data from 2017 to 2020 , and the data results are shown in Table 1-5.

Table 1. Main business income composition of Trans Tech

\begin{tabular}{|c|c|c|c|c|c|c|c|c|}
\hline \multicolumn{9}{|c|}{ Main business income composition } \\
\hline \multirow[b]{2}{*}{ Main business } & \multicolumn{2}{|c|}{2017} & \multicolumn{2}{|c|}{2018} & \multicolumn{2}{|c|}{2019} & \multicolumn{2}{|c|}{$2020.01-06$} \\
\hline & Amount & Proportion & Amount & Proportion & Amount & Proportion & Amount & Proportion \\
\hline & $(¥ M)$ & $(\%)$ & $(¥ M)$ & $(\%)$ & $(¥ M)$ & $(\%)$ & $(¥ M)$ & (\%) \\
\hline ETC & 18276.86 & 99.83 & 23748.74 & 93.75 & 137267.52 & 95.95 & 11992.61 & 71.34 \\
\hline $\begin{array}{l}\text { operation } \\
\text { management } \\
\text { system }\end{array}$ & - & 0.00 & 651.88 & 2.57 & 4716.43 & 3.30 & 4594.64 & 27.33 \\
\hline $\begin{array}{l}\text { Derivative } \\
\text { services }\end{array}$ & 31.11 & 0.17 & 930.08 & 3.67 & 1072.88 & 0.75 & 223.82 & 1.33 \\
\hline Total & 18307.97 & 100.00 & 25330.71 & 100.00 & 143056.82 & 100.00 & 16811.07 & 100.00 \\
\hline
\end{tabular}

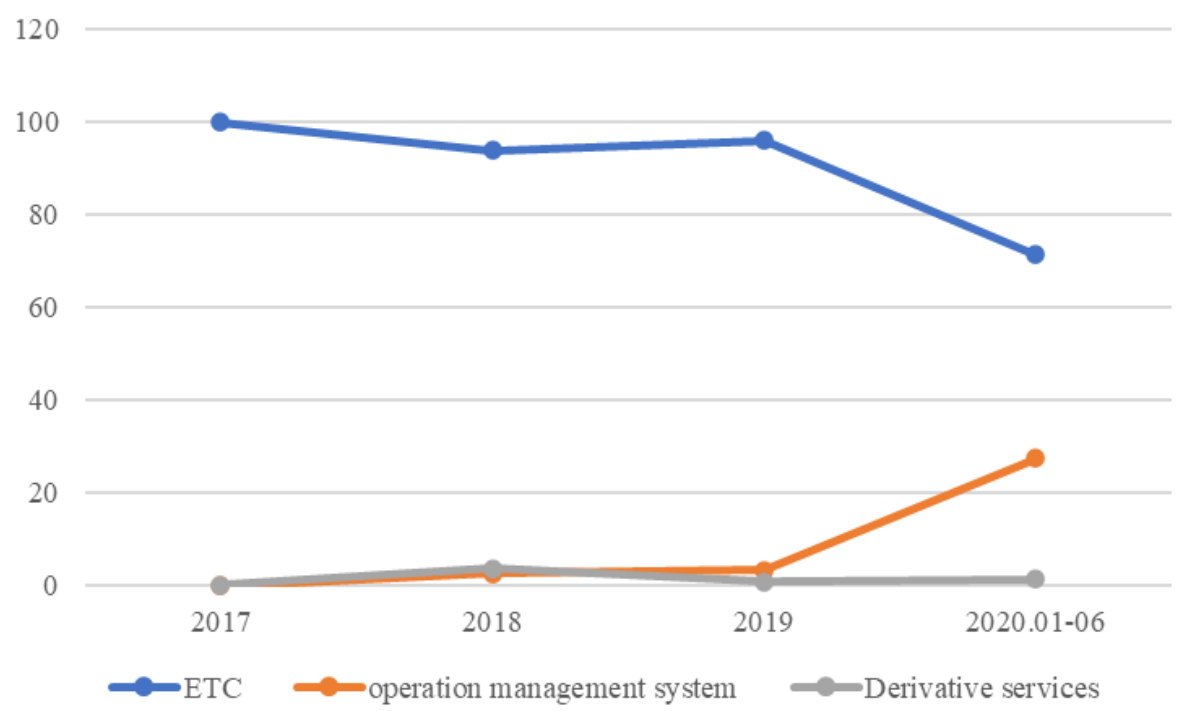

Fig.1. main business proportion line chart.

From Fig.1. and Table 1 above shows that ETC is still the most important source of operating income, and capital spent on operation management systems and derivative services is increasing slowly from 2017 to 2019. The main reason for the decrease in 2020 was the influence of COVID-19. A sharp increase happened in
2020 in the operation management system, from $3.3 \%$ to $27.33 \%$. All these trends can illustrate that Trans Tech lays great stress on scientific and technological innovation, which is vital to the improvement of the company's competitiveness.

Table 2. Main business cost composition of Trans Tech

\begin{tabular}{|c|c|c|c|c|c|c|c|c|}
\hline \multicolumn{9}{|c|}{ Main business cost composition } \\
\hline \multirow{3}{*}{ Main business } & \multicolumn{2}{|c|}{2017} & \multicolumn{2}{|c|}{2018} & \multicolumn{2}{|c|}{2019} & \multicolumn{2}{|c|}{ 2020.01-06 } \\
\hline & Amount & Proportion & Amount & Proportion & Amount & Proportion & Amount & Proportion \\
\hline & $(¥ M)$ & (\%) & $(¥ M)$ & $(\%)$ & $(¥ M)$ & $(\%)$ & $(¥ M)$ & $(\%)$ \\
\hline
\end{tabular}




$\begin{array}{ccccccccc}\text { ETC } & 13962.75 & 99.94 & 16083.25 & 97.40 & 80552.98 & 97.75 & 8035.95 & 77.08 \\ \begin{array}{c}\text { operation } \\ \text { management } \\ \text { system }\end{array} & - & 0.00 & 178.46 & 1.08 & 1506.60 & 1.83 & 2246.90 & 21.55 \\ \begin{array}{c}\text { Derivative } \\ \text { services }\end{array} & 8.42 & 0.06 & 250.41 & 1.52 & 344.75 & 0.42 & 142.72 & 1.37 \\ \quad \text { Total } & 13971.17 & 100.00 & 16512.12 & 100.00 & 82404.33 & 100.00 & 10425.57 & 100.00\end{array}$

In 2017, the company focused on ETC and put 99.94\% of its cost when the company hasn't carried out the operation management system. Trans Tech also cost $¥ 8.42 \mathrm{M}$ in derivative services, which occupied $0.06 \%$ of the whole cost composition. In 2018, the company's operating costs increased by $18.19 \%$ compared with the previous year, and the operating income increased by $38.36 \%$, which is $¥ 16512.12 \mathrm{M}$. The company began to work on an operation management system which has already accounted for $1.08 \%$ of all three businesses. In 2019 , the percentage of costs in all of the company' $\mathrm{s}$ operations was leveling off. The ETC is still the key project of the company, which cost $¥ 80552.98 \mathrm{M}$. However, the whole cost of Trans Tech dropped in 2020 because the data collected are for only half a year. In addition, due to COVID-19, the highway was free for 79 days which has had a huge negative impact on ETC business. For this year, with the national epidemic improving, the company's performance is expected to improve.

\subsection{Financing Situation}

In this part, we will analyze the financing situation of the company to see whether it has potential investment value. As illustrated in Table 3, Trans Tech has received the capital from the Jiangsu Province Government (Jiangsu Communications Holdings Co, Ltd. and Jiangsu Expressway Network operation \& Management Center), which means that there is no risk of bankruptcy. What's more, we can see several big investors like Tencent and Shanghai Lianyin invest in Trans Tech in series A and A+ rounds. In series A, Shanghai Lianyin invested $¥ 6 \mathrm{M}$. Shanghai Equity invested $¥ 5 \mathrm{M}$ while the Nantong Traffic Technology Electronic Technology Industry Development invested $¥ 4 \mathrm{M}$. In series A+, Tencent invested $¥ 49.64 \mathrm{M}$, of which $¥ 9 \mathrm{M}$ was included in the capital stock of the company and Hainan Fapiaoer Science and Technology invested $¥ 44.13 \mathrm{M}$, of which $¥$ $8 \mathrm{M}$ was included in the capital stock of Trans Tech. From the investor list, we can see that these are all cathedratic companies and their decisions are usually well thought out. Such companies will also influence the investment decisions of some VCs in the market. Here comes the conclusion: Trans Tech is a promising company from its financing situation.

Table 3.Financial rounds (Founders)

\begin{tabular}{ccc}
\hline Founders & Amount( $¥)$ & Proportion \\
\hline Jiangsu Communications Holdings Co, Ltd. & $70 \mathrm{M}$ & $70 \%$ \\
Jiangsu Expressway Network operation \& Management Center & $30 \mathrm{M}$ & $30 \%$ \\
Total & $100 \mathrm{M}$ & $100 \%$ \\
\hline
\end{tabular}

Table 4.Financial rounds (Series A)

\begin{tabular}{ccc}
\hline Shareholders (Series A) & Amount( $¥)$ & Proportion \\
\hline Jiangsu Communications Holdings Co, Ltd. & $70 \mathrm{M}$ & $60.87 \%$ \\
Siangsu Expressway Network Operation \& Management Center & $30 \mathrm{M}$ & $26.09 \%$ \\
& & $5.22 \%$
\end{tabular}


Table 5.Financial rounds (Series A+)

\begin{tabular}{ccc}
\hline Investors (Series A+) & Amount( $¥)$ & Proportion \\
\hline Tencent Cloud Computing (Beijing) Co, Ltd. & $9 \mathrm{M}$ & $2.59 \%$ \\
Hainan Fapiaoer Science and Technology Co, Ltd. & $8 \mathrm{M}$ & $2.31 \%$ \\
Total & $17 \mathrm{M}$ & $4.90 \%$ \\
\hline
\end{tabular}

\section{POCD ANALYSIS}

POCD framework has four dynamic components of any entrepreneurial process or venture: people, opportunity, context, and deal. The so-called people refer to the people and individuals who meet the company's needs for the company, such as auditors, suppliers, etc. The so-called opportunity refers to the extremely small investment in the present to win great returns in the future. The so-called context refers to external factors, such as unpredictable external influences such as interest rates in the macro economy or industry competition.

\subsection{Analysis based on people}

First of all, Trans Tech has a professional, mature and stable core team whose members engage in industryrelated work for a long time, and all of them have rich technical and management experience. Also, they will integrate innovative ideas into products, which provides a solid foundation for the company's development. However, because the company is still at an early stage, the size of the technical team is a little bit small, which leads to a certain limitation to Trans Tech's project undertaking ability.

Secondly, the actual controller is the Jiangsu Provincial Government State-owned Assets Supervision and Admission Commission - an agency of local government that holds an $82.70 \%$ stake. What's more, the two founders (Jiangsu Communicating Holding Co, Ltd and Jiangsu Expressway Network Operation \& Management Center) are controlled by the Government of Jiangsu Province. These facts discussed above mean that Trans Tech is a state-owned company.

As a Chinese state-owned company, it will receive the state capital and strong state support. Our country will create external advantages consciously to help this type of company. But on the other side, most SOE leaders will take a wait-and-see attitude towards changes that is not conducive to the company's reform.

In addition, a majority of the members of the board, like Mr.Wang and Mr.Xu, have strong financial skills and many years of experience in the intelligent transport industry, which makes their decisions more reliable and operable. To sum up, Trans Tech has a comparative advantage in terms of People.

\subsection{Analysis based on opportunity}

\subsubsection{The opportunity for ETC markets}

First of all, there is a huge market for parking fees.

ETC parking lot can effectively solve the problems of queuing congestion, labor cost, and dynamic pricing and improve the operation efficiency and profitability of the parking lot. According to the Implementation Plan for Accelerating the Application of Expressway Electronic Non-parking Toll Express jointly issued by the National Development and Reform Commission and the Ministry of Transport, by the end of December 2020, the parking scene of airports, railway stations, passenger stations, ports, and other large traffic stations will be covered by all ETC services.

Secondly, ETC will enter the automobile front assembly system.

According to the "23 [2019]" document issued by the State Office of the General Office of the State Council, the Ministry of Industry and Information Technology (MIIT) is required to be responsible for promoting the prefabrication and installation of automobiles. The Ministry of Transport is required to complete the formulation of technical standards for ETC vehicle devices by the end of 2019. From 1 July 2020, the vehicle type newly applied for approval should add an ETC vehicle-mounted device in the optional configuration. 


\subsubsection{The threats for ETC markets}

First of all, the risk of highway tolls may reduce or exempt. In accordance with the relevant provisions of the regulations on the Administration of Toll roads, the maximum period of tolling for operational highways shall not exceed 25 years. In accordance with the principle of recovering investment and having a reasonable return, and the maximum period of tolling for operational highways in central and western provinces, autonomous regions and municipalities directly under the Central Government shall not exceed 30 years as determined by the state. Under the background of limited local government financial revenue, highway construction funds need to be solved by bank loans or other debt financings. The expressway's later operation and maintenance costs are also higher, so limited by local financial funds, the possibility of free passage of expressway in our country are less in a short period.
Secondly, the risk of performance impact on the decline of precipitation funds of ETC stored value card.

If the expressway's toll is not extended after the expiration of toll years in the future, or if the local finance buys out the toll right of the expressway, it will lead to the reduction of toll charge of the expressway then the corresponding electricity to the company. The revenue of sub-charge business has a negative impact. In May 2019, the State Development and Reform Commission and the Ministry of Transport called for the suspension of the issuance of ETC stored value cards and the gradual reduction of ETC storage. The value card is used. After May 2019, although the ETC stored value card issued by the issuer can continue to be used, and some users are still used to using the stored value card, the balance of funds deposited by the issuer's stored value card still shows a downward trend. At the end of the reporting period, the balance of the issuer's ETC stored value card was as follows:

Table 6. ETC stored value balance

\begin{tabular}{lllll}
\hline & $2020 / 6 / 30$ & $2019 / 12 / 31$ & $2018 / 12 / 31$ & $2017 / 12 / 31$ \\
\hline $\begin{array}{l}\text { ETC stored value } \\
\text { balance }\end{array}$ & $222,681.38 \mathrm{M}$ & $235,660.44 \mathrm{M}$ & $249,899.85 \mathrm{M}$ & $224,799.79 \mathrm{M}$ \\
Modifying Ratio & $-5.50 \%$ & $-5.70 \%$ & $11.17 \%$ & - \\
\hline
\end{tabular}

However, suppose the recharge amount of the stock ETC stored value card users continues to decline or no longer recharge. In that case, it will lead to the decline of the issuer's capital income, which will have a negative impact on the issuer's performance.

To sum up, For Trans Tech, the country's policies may be both an opportunity and a threat. With urbanization and the increasing number of vehicles, traffic congestion has been a great issue. To relieve the phenomenon, the country advances a number of policies, which promotes the rapid spread of ETC. Besides, national documents have been required to extend ETC application scenarios, such as petrol stations and parking lots in airports or railway stations. Indeed, Trans Tech has initially built its business in these areas, and the policies just pave the way for it. Granted, a policy stating that the longest period of operating toll road may not exceed 30 years is not beneficial to the company's long run. But in our investment period, which is generally less than 10 years, Trans Tech will lie in a stable developing environment.

\subsection{Analysis based on context}

First of all, the completion in the industry -Weak power. Competitors in the industry are a weakness for Trans Tech. As mentioned previously, Trans Tech tends to expand its business in other provinces. However, those provinces already exist competitive companies, most of whom are also controlled by local governments and even have acquired a monopoly. So, it does be a challenge to explore its field outside Jiangsu province.

Secondly, the potential of new entrants into the industry- relatively low. The ETC business should be state-controlled, and the sales, installation, and recharge services of ETC are businesses handled by expressway operation and management units. In addition, highway ETC equipment implements a product qualification access system. Only after the company's products have passed the inspection by the Ministry of Transport's Traffic Engineering Supervision and Inspection Center authorized by the Ministry of Transport can it participate in the bidding for the ETC construction of highways in various provinces and cities. The barrier for entry is relatively higher than the usual industry.

Lastly, customer power-relatively moderate. First of all, there are three expressway toll modes in the market. The first one is the manual toll collections model. Currently, $80 \%$ of manual toll modes collection has been abandoned. The machine will automatically calculate the fees that need to be charged, but the payment and card issuance are handled manually. The last one is the ETC service. No manual work is required. The system senses the OUB installed on the vehicle and releases it directly. Although ETC has many advantages and the cooperative banks also offer a lot of preferential treatment, it is relatively more expensive than semi-automatic labor, so some customers prefer the second kind of semi-manual service. However, due to the policy issued by the 
government, it will gradually replace the semi-manual toll station and gradually turn into ETC, which will fully cover ETC service. It is an opportunity for the ETC industry. Customers indeed have the right to choose at will, but the current policy favors the uniform conversion of all pricing models to ETC.

\section{COMPETITION ANALYSIS}

After years of development, Trans Tech has become one of the most competitive companies that supply intelligent transportation platforms for roads. With a strong ability of software research and development and independent innovation, Trans Tech has won a primary position in Jiangsu province and had its initial cooperation with other provinces, such as Hunan, Beijing, Shanghai, and so on. Nevertheless, there standing some threatening competitors, like Shandong High Speed Xinlian Technology Co., Ltd., and most of the monopolies in their local province. So, it's important to analyze the company's comparable advantages and disadvantages.

\subsection{Advantages}

Firstly, technology superiority plays a significant role in its development. Insisting on innovation promotion and technology research, Trans Tech put forward the Construction Method of Multi-functional Sensing Traffic Platform and Standard System Framework for the first time, which motivates the digitization transformation of the highway industry. Besides, the company made it possible to aggregate and share information or resources through the cloud network based on big data analysis and cloud computing. This could facilitate taking highway tolls among different regions. Because of technology development, Trans Tech's issued ETC numbers have ranked second among the transportation industry.

Secondly, it has marketing application advantages. Based upon the technology superiority above, after years of operation, Trans Tech has been rich in implementation experience and owned a large number of outstanding project achievements, such as Internet + ETC smart parking cloud service platform and new-generation research on ETC charging systems. Trans Tech has also established a mature operation model and product chain, which can be spread and put into practice quickly. Hence, there is no doubt that plentiful market application experience won its future development and business expansion to other provinces.

Thirdly, it also has strategy synergy advantages. By building business relationships with companies or unions in distinguished areas, Trans Tech enlarged ETC application scenarios successfully. For example, by using Union Pay's role as a national inter-bank clearing network, Trans Tech formed an inter-provincial business and an inter-scenario payment and settlement system. By cooperating with SAIC Motor, which occupies a great part of the car industry, Trans Tech can better issue more ETC and aggregate resources. By means of Tencent's billions of users' data, information flow, and rich scene resources, Trans Tech improved its service ability of ETC in non-highway payment, such as intelligent parking lots, no-sensing petrol stations, and commercial logistics.

\subsection{Disadvantages}

First and foremost, the company is relatively young, and the scale of business and personnel is relatively small. Considering the company is in an active expansion stage, and its demand for market personnel and technical personnel has increased. Besides, due to the nature of the company's business, the company needs to recruit many workers to provide timely operation and maintenance services in previous projects locations. Therefore, the company's current scale limits its ability to undertake projects to a certain extent.

Moreover, although Trans Tech is in a monopoly position in Jiangsu Province and has high brand awareness, it just penetrated other regional markets shallowly, and markets outside the province still need more effort to explore. Those state-owned companies still hold sturdy control right.

\section{DISCUSSION}

\subsection{Investment Decision}

Analyzing Trans Tech's merits and demerits with the POC framework and its competitive capacity, it concludes that we'll invest in Trans Tech.

In accordance with analysis using the POC framework, all three aspects (People, Opportunity, Context) have their strengths outweighed their weaknesses. And definitely, competition analysis shows that the primary three factors of its success are its technological superiority, sophisticated marketing application, and efficient strategy synergy. Also, the nature of the enterprise works as the intrinsic driving force in its way. Although the coAAPOCmpany is relatively young, and we have to admit that its business expansion is restrictive, the connection of provincial networks into a national highway grid improves convenience for charging over the country and promotes the development of intelligent transportation and autonomous driving. Last but not least, data shows that Jiangsu provincial highways are comparatively more profitable. All of these inspire Trans Tech to be a promising company. Therefore, we consider it a wise choice to be Trans Tech's investor. 


\subsection{Development Suggestions}

Now that Trans Tech has a monopoly in Jiangsu province and it's a leading company in its area, we must admit that Trans Tech is in a safe but limited place in Jiangsu. To have better development, it must fight to survive in other provinces.

In the provinces in which Trans Tech has penetrated projects, it can broaden the market with elaborated marketing approaches. For instant, set the lower price to large-scale consumers and present individual consumers with a meal or car-washing coupons. While appealing to more people, the company can also persuade local governments to deeper cooperation with its unique standard systems, multi-sensing platforms, and achievements in different regions.

Besides, since Trans Tech is a state-owned company and is intimate with Jiangsu governments, the company can propose a characterized regional transport network with neighboring governments coalition. In this way, Trans Tech's business can extend its operation areas, but with more favorable transportation, Jiangsu's prospective economy can drive development in surrounding provinces, particularly Anhui province.

\section{CONCLUSION}

Through analysis of main business and profit situation, Trans Tech adopts the strategic method of diversified layout and generates large amounts of revenue from ETC. What's more, the company also attaches great importance to innovation, actively initiate and capture the business of new intelligent transportation filed like operation management systems and derivative services. All these illustrate that the future development prospects of the company are broad and clear. In addition, Trans Tech has received capital from cathedratic companies like Tencent, and it is also supported by the Jiangsu Province Government, which means that the future development of the company will be very stable, there is no risk of bankruptcy.

Moreover, Analysis by the POC framework also confirms our conclusion above, so it comes to our decision to invest in its Initial Public Offering (IPO). But considering young as it is and hoping that investment revenue won't be out of our expectation, we have proposed that Trans Tech cultivate a good relationship with other governments, get insight into its fields, and then inroad into provinces neighboring Jiangsu province. These approaches are uncertainly beneficial in increasing the overall value and appealing to more investors to propel its development.

A POCD framework is widely used and carried out by corporate firms and businesses to study and understand the environment and market they operate. A POCD framework evaluates two main external factors - opportunity, content, which change over time and need constant attention and review. Since external factors are based on assumptions and macro economic conditions, they are a barrier to the transparency of POCD analysis and make it vulnerable to discrepancies. Firms might need to employ or outsource expert research \& development workforce bound to the analysis. This increases expenses and costs, plus capital resources, bad assessment, or weak analysis might result in losses for the company.

Secondly, POCD Framework does not include the analysis of industry competition. Although the company itself may have a lot of patents and development advantages, if you don't know the level of industrial development, if there are some disruptive innovations or incremental innovations, then the company's position will be at risk.

In view of the above two points, I suggest adding Porter Five the Analysis, which focuses on industry analysis, to analyze the competition situation of the industry. At the same time, PESTLE analysis is added to analyze the influence of external factors, especially economy and environment, on the company's development from multiple perspectives.

\section{REFERENCES}

[1] Croce, A., Marti, J. , \& Murtinu, S. . (2013). The impact of venture capital on the productivity growth of European entrepreneurial firms: 'screening' or 'value added' effect?. Journal of Business Venturing, 28(4), 489-510.

[2] Sahlman, W. A. . (1990). The structure and governance of venture-capital organizations. Journal of Financial Economics, 27(2), 473-521.

[3] Dong Jing, Zhao Guozhen \& Chen Wenfeng. (2021). Will the involvement of venture capital affect the business model of startups? Foreign Economics and Management (04),64-84 doi:10.16538/j.cnki.fem.20210228.101

[4] Sapienza, H. J. , Manigart, S. , \& Vermeir, W. . (1995). A comparison of venture capitalist governance and value-added in the u.s. and western europe. Academy of Management Annual Meeting Proceedings, 1995(1), 105-109.

[5] SØ, M. , \& RENSEN. (2007). How smart is smart money? a two-sided matching model of venture capital. Journal of Finance, 62(6), 2725-2762.

[6] Megginson, W. L. , \& Weiss, K. A. . (1991). Venture capitalist certification in initial public offerings. The Journal of Finance, 46(3), 879-903.

[7] Steven, N., Kaplan, Per, \& Strömberg. (2003). Financial contracting theory meets the real world: an 
empirical analysis of venture capital contracts. Review of Economic Studies.

[8] Krishnan, C. , \& Nguyen, D. . (2020). Investment proximity and venture capital returns. SSRN Electronic Journal.

[9] Kuruva, R. , \& Annamalai, T. . (2020). Corporate Tax Havens and Venture Capital Investment.

[10] Ying, G., Zhang, L., Yue, Q. , \& Chao, Y. . (2017). Venture Capital and Patent Activities in China: Multi-Case Study in Bio-Pharmaceutical Industry. 2017 Portland International Conference on Management of Engineering and Technology (PICMET).

[11] Yang, H. . (2020). Venture capital decision based on fpga and machine learning. Microprocessors and Microsystems, 103457.

[12] Sahlman, W. A. . (1999). Some thoughts on business plans. 